\title{
TRANSFORMING ROMANIA INTO A KNOWLEDGE ECONOMY THROUGH ICT - CURRENT DEVELOPMENTS
}

\author{
Mădălina TOCAN*, Oana CHINDRIȘ-VĂSIOIU**, Anca CRISTEA***, \\ Ileana MĂRGINEAN**
*Ecological University of Bucharest, Institute of National Economy, Bucharest, Romania
** Institute of National Economy, Bucharest, Romania
$* * *$ Hyperion University, Institute of National Economy, Bucharest, Romania
madalina.tocan@gmail.com, oana.vasioiu@gmail.com, lcancacristea@yahoo.com, ileanamarginean40@gmail.com

\begin{abstract}
In a society dependent on information, knowledge seems to be the only power that guarantees socio-economic development and progress. The knowledge is considered to be the driving force of economic growth and a resource that can provide sustainable competitive advantage and for this reason generates a great interest in understanding knowledge, information, technology, learning and their role in social economic life.

In this society in which knowledge occupies an important place, information and communication technology represents an important pillar because without it the transmission of knowledge cannot be achieved. From this perspective, this paper tries to present the current stage of development of the ICT sector in Romania and to propose some solutions to improve it.
\end{abstract}

Keywords: Knowledge economy, digitalization, Romania, information and communications technologies

\section{Introduction}

Information and communications technologies represent a pillar of the knowledge-based economy, because without it, knowledge transmission cannot be achieved. At the same time, the knowledge-based economy cannot be conceived even without content products that digitize knowledge itself [1].

A number of emerging trends in the global ICT sector are drivers of growth, innovation, changing business models and even the disruption of various economic sectors. Among the important trends we can mention [2]:

Connectivity: Electronic communications networks are gradually becoming channels for mass consumption of multimedia content (music, movies, live broadcasts), for the widespread use of a large number of diversified applications and services (social networks, payment applications and ecommerce) and even for the remote control of various types of devices (sensors, video cameras, etc.).

Ubiquitous internet access: fixed (point) internet solutions are an already established method for connecting to the internet of many households and businesses worldwide.

Business digitalisation increases business productivity and contributes to increasing consumer satisfaction, with a positive effect on turnover [3]. The full realization of the 
$5 \mathrm{G}$ benefits at global level is expected by 2035, when the annual production of "5G enabled" products and services is forecast at USD 12.3 trillion [4].

The Internet of Things (IoT) represents, in terms of connectivity, an important innovation from economic and social point of view. Through IoT, it can be realized a network between objects and people through Internet. IoT can create intelligent ecosystems that perceive the environment, analyse and adapt in order to make our lives more safe and efficient. The significant increase in the number of IoT-connected objects at average annual rates of over $20 \%$ by 2022 [5] will be fuelled by an increasingly diverse range of usage scenarios and lower prices of connected devices / things.

Cyber security, trust and data sovereignty: the proliferation of IoT and the serving of more and more industries with personalized services mean that an increasing volume of private information, sometimes with high commercial sensitivity, is transported through communications networks. Due to the heterogeneous possibilities of network access, combined with advanced data processing techniques and the extraction of knowledge from them, data loss or their illegitimate use can have severe consequences. Thus, securing communications infrastructures must be accompanied by securing services from their design, through a user-cantered approach.

\section{ICT in Romania}

In recent decades the Central and Eastern Europe countries have had a remarkable development. Between 2004 and 2019, the GDP per capita in the Central and Eastern Europe countries had an increasing of $115 \%$. This success of the CEE countries has been largely due to consolidation of the The present ITC sector performance is not very favourable for Romania because economy, lower labour costs, increasing exports and foreign investment, the efficient utilization of the European Union funding. This growth trajectory can be maintained through digitization. Central and Eastern Europe countries can obtain economic benefits from digitization, mainly due to possible productivity increases [6].

In 2017-2019, the digital economy in CEE countries grew by approximately $8 \%$ per year and the growth rate was superior to the growth rate of the "Big 5" - France, Germany, Italy, Spain and the United Kingdom. Between January and May 2020, the digital economy in the CEE countries had an impressive growth, reaching in the first 5 months of $202078 \%$ of the growth recorded in 2019 [6].

Due to recent developments, we can say that in the near future the world will be more digitalized. The current pandemic has shown how important digitalisation is for national economies, allowing work and economic activities to continue in many sectors of activity, the exchange of information on the spread and treatment of Sars Cov2 infection, the acceleration of the medicines and vaccines search.

Romania is an important regional centre for software developers, several cities being associated with the IT sector. Among them is not only Bucharest, but also Cluj, being often mentioned as "Silicon Valley of Europe", Timisoara, Iasi or Brasov. Statistics show that Romania has a higher number of software developers per capita than in the United States, China or Russia. IT\&C specialists in Romania are especially famous for software development, web pages or fintech. Regarding the number of employees in the ITC sector, Romania has a high level, having almost 200 thousand specialists and being close to the level of the Czech Republic [7]. 
according to the DESI 2020 report Romania occupied the 26th rank from the of $28 \mathrm{EU}$ member states.

The digital performance of Romania has not changed in the case of four out of five dimensions measured by DESI. Romania has achieved the best results in terms of connectivity due to the use of very high speed broadband services (at least 100 Mbps) in 49\% of homes in Romania [8]. However, Romania's performance is the lowest among EU Member States in terms of digital public services and the use of internet services.

Table 1 Romania's position in DESI 2020

\begin{tabular}{|l|l|l|l|l|}
\hline \multicolumn{1}{|c|}{ DESI dimensions } & $\begin{array}{c}\text { Romania } \\
\text { Score }\end{array}$ & $\begin{array}{c}\text { EU } \\
\text { Score }\end{array}$ & \multicolumn{1}{c|}{$\begin{array}{c}\text { Maximum } \\
\text { score }\end{array}$} & $\begin{array}{c}\text { Romania's } \\
\text { rank }\end{array}$ \\
\hline Connectivity & 14 & 12.5 & 16.5 (Denmark) & 11 \\
\hline Digital competences & 8.29 & 12.3 & 19.6 (Finland) & 27 \\
\hline Use of internet services & 5.38 & 8.7 & 11.5 (Finland) & 28 \\
\hline Integration of digital technology & 6.51 & 8.27 & 14.9 (Irland) & 27 \\
\hline Digital public services & 7.26 & 10.8 & 13.4 (Estonia) & 28 \\
\hline
\end{tabular}

Source: Data processed by author based on European Commission DESI 2020 report.

In terms of connectivity Romania ranks 11th among EU member states. Romania has very good results in the indicators fixed very high capacity networks (VHCNs) and the use of broadband services of at least 100 Mbps (68\% and 49\%, respectively). In terms of the use of broadband services of at least 100 Mbps, Romania still exceeds the EU average ( $49 \%$ compared to $26 \%$ in EU) but lagged behind in terms of $4 \mathrm{G}$ coverage (85\%, ranking well below the EU average of $96 \%$ ). Regarding the degree of readiness for the $5 \mathrm{G}$ use, Romania has a score of $21 \%$, similar to the EU average.

Table 2 Connectivity dimension in Romania and EU

\begin{tabular}{|l|l|l|}
\hline \multicolumn{1}{|c|}{ Connectivity indicator } & Romania & UE \\
\hline Overall fixed broadband take-up (\% households) & $66 \%$ & $78 \%$ \\
\hline At least 100 Mbps fixed broadband take-up (\% households) & $49 \%$ & $26 \%$ \\
\hline Fast broadband (NGA) coverage (\% households) & $82 \%$ & $86 \%$ \\
\hline Fixed Very High Capacity Network (VHCN) coverage(\% households) & $68 \%$ & $44 \%$ \\
\hline 4G coverage(\% households) & $85 \%$ & $96 \%$ \\
\hline $\begin{array}{l}\text { Mobile broadband take-up } \\
\text { Subscriptions per 100 people }\end{array}$ & 86 & 100 \\
\hline $\begin{array}{l}\text { 5G readiness } \\
\text { Assigned spectrum as a \% of total harmonised 5G spectrum }\end{array}$ & $21 \%$ & $21 \%$ \\
\hline $\begin{array}{l}\text { Broadband price index } \\
\text { Score (0-100) }\end{array}$ & 92 & 64 \\
\hline
\end{tabular}

Source: Data processed by author based on European Commission DESI 2020 report

From the human capital point of view, Romania ranks 27 th out of the 28 EU countries. Romania registers a higher value than the EU average in the case of ITC graduates, with $5.6 \%$ of all graduates (compared to the EU average of 3.6\%).
The levels of at least basic digital skills and at least basic software skills are far below the EU average. Compared with the EU average of $58 \%, 31 \%$ of Romanians have at least basic digital skills. In the same time occupies also a weak position in terms of 
basic software skills, $35 \%$ of Romanians having basic software skills (compared to EU average of $61 \%$ ). Only $10 \%$ of people have above basic digital skills and for this reason Romania occupies the last position in EU. Romania's unfavourable is consolidated by the percentage of ICT specialists, they representing only $2.2 \%$ of the workforce, while in EU the average being $3.9 \%$.

Table 3 Human capital dimension in Romania and EU

\begin{tabular}{|l|l|l|}
\hline \multicolumn{1}{|c|}{ Human capital indicator } & Romania & \multicolumn{1}{c|}{ EU } \\
\hline At least basic digital skills(\% individuals) & $31 \%$ & $58 \%$ \\
\hline Above basic digital skills(\% individuals) & $10 \%$ & $33 \%$ \\
\hline At least basic software skills(\%individuals) & $35 \%$ & $61 \%$ \\
\hline ICT specialists (\% total employment) & $2,2 \%$ & $3,9 \%$ \\
\hline Female ICT specialists (\% female employment) & $1,2 \%$ & $1,4 \%$ \\
\hline ICT graduates( \%graduates) & $5,6 \%$ & $3,6 \%$ \\
\hline
\end{tabular}

Source: Source: Data processed by author based on European Commission DESI 2020 report

Romania's weak position is sustained by the lowest level of Internet services use. $18 \%$ of people aged 16 to 74 have never used the internet (EU average: 9\%). However, there are two online activities in which Romania ranks 6th in the EU. These are the use of social networks $(82 \%$, compared to an EU average of $65 \%$ ) and video calls (67\%; EU average: 60\%).In contrast, the use of online banking (11\%), shopping $(29 \%)$, reading news $(55 \%)$, as well as the consumption of music, videos and online games $(63 \%)$ are the lowest among EU Member States. [8]. The low level of online banking services use is due to the fact that more than two out of five Romanian adults (42\%) do not have a bank account [9].

Compared with the EU average, the utilization of digital technology by companies in Romania is much lower, $23 \%$ of Romanian companies exchanging information electronically, $8 \%$ using social communication platforms (EU average: $25 \%$ ) and $11 \%$. make online sales (EU average of $18 \%$ ).

Also, in the last three years the utilization of the digital public services puts Romania in the last position in EU. In contrast, Romania ranks 8 th in terms of users of egovernment services, with $82 \%$ of Internet users, compared with the EU average of $67 \%$.

In order to deal with the crisis caused by the COVID-19 pandemic Romania has taken several specific measures in the information technology field. Among these measures we can mention:

- the application of the Ministry of Health used to centralize the data regarding the number of infected people;

- creation of a website for the electronic transmission of the necessary documentation for granting technical unemployment (https://aici.gov.ro);

- creating information websites for citizens to provide clear and concise information about the Sars Cov2 virus and to combat misinformation (https://stirioficiale.ro/, https://datelazi.ro/, https://fiipregatit.ro)

- the adoption of a Government Decision on May 7, 2020, by which the budget of the Ministry of Education for 2020 was supplemented with the amount of RON 150 million (approximately EUR 24 million), for the purchase of laptops for 250,000 children. The aim was to ensure access to distance learning activities for students from disadvantaged areas enrolled in pre-university education units. 


\section{Conclusions}

The results of the analysis show the improvement of ITC sector development in Romania. But nevertheless, Romania is on the penultimate place in Europe in terms of digital competitiveness Although we are proud of both our cheap and fast internet services and an IT industry, in fact, these achievements hide the fact that we are lagging behind with the essential infrastructure and skills that would allow us to adapt to the economy of the 21 st century. Although it may seem only a passing fad in the world of corporations, digitalization is an indispensable element for the recovery and development of the Romanian economy. In this context, the EU is committed to supporting economic recovery in view of the transition to climate neutrality and resilient digital transformation. For this reason, the development of the population digital skills, the organizations and public administration digitalization are essential for a solid recovery.

A solution for the Romania's digitalization and the development of the ICT sector is the efficient use of the non-reimbursable funds allocated by the EU for the financing of various projects. Thus, a financing facility is represented by the continuation of the European Interconnection Mechanism [10], an initiative of the European Commission in collaboration with the European Investment Bank for the development of cross-border transport, communications and energy networks, and in the period 2021-2027, with the aim to support investments in cross-border transport infrastructure (including smart and autonomous transport), energy and digital transport [11]. Too these will be added funding available through the Digital Europe Program in five directions: supercomputers, artificial intelligence, cyber security, advanced digital skills and the widespread use of digital technologies. In addition, the new Invest EU Program will provide funding in particular to the private sector for projects that support the development of high-capacity digital networks and the development and operationalization of digital services and technologies.

\section{References List}

[1] Caragea, A., Gheorghiu, R., Turlea, G., Economia Bazată pe Cunoaştere în România, available https://acad.ro/rpcie/jul/doc/raport ke.doc

[2] Strategia 5G pentru Romania, available at https://www.comunicatii.gov.ro/wpcontent/uploads/2019/09/Strategia-5G.pdf.

[3] Little, A.D., Reimagining telco operations in a hyper-digital world, available at https://www.adlittle.com/sites/default/files/viewpoints/adl_reimagining_telco_operation $\mathrm{s}$ in a hyper-digital world $0 . p d f$

[4] Qualcomm, 5G is Driving Economic Growth, Resiliency, and Sustainability, available at https://www.qualcomm.com/5g/the-5g-economy

[5] Heuveldop, N., Ericsson Mobility Report, available at https://www.ericsson.com/assets/local/mobility-report/documents/2017/ericsson-mobility-report-june2017.pdf

[6] Marciniak, T., Novak, J., Pastusiak, B., Purta, M., Digital Challengers in the next normal in Central and Eastern Europe, available at https://www.mckinsey.com/business-functions/mckinsey-digital/our-insights/digitalchallengers-in-the-next-normal-in-central-and-eastern-europe 
[7] Asociația Patronală a Industriei de Software și Servicii, Studiu-asupra-economieidigitale-din-Romania, available at https://anis.ro/wp-content/uploads/Studiu-asupraeconomiei-digitale-din-Romania 2021-1.pdf

[8] European Commission, Digital Economy and Society Index 2020, available at https://ec.europa.eu/digital-single-market/en/digital-economy-and-society-index-desi

[9] Banca Mondială, Global Findex Database 2017, available at https://globalfindex.worldbank.org/

[10] European Commission, A common infrastructure financing instrument for 2014-2020, available at https://ec.europa.eu/info/business-economy-euro/growth-andinvestment/financing-investment/connecting-europe-facility-cef-financialinstruments en\#a-common-infrastructure-financing-instrument-for-2014-2020

[11] European Commission, Commission proposes increased funding to invest in connecting Europeans with high-performance infrastructure, available at https://ec.europa.eu/commission/presscorner/detail/en/IP_18_4029\#_ftn1 